This is an electronic reprint of the original article. This reprint may differ from the original in pagination and typographic detail.

Author(s): Posti-Ahokas, Hanna; Lehtomäki, Elina

Title: $\quad$ The significance of student voice: female students' interpretations of failure in Tanzanian secondary education

Year: $\quad 2014$

Version:

Please cite the original version:

Posti-Ahokas, H., \& Lehtomäki, E. (2014). The significance of student voice: female students' interpretations of failure in Tanzanian secondary education. Gender and Education, 26(4), 338-355. https://doi.org/10.1080/09540253.2014.907392

All material supplied via JYX is protected by copyright and other intellectual property rights, and duplication or sale of all or part of any of the repository collections is not permitted, except that material may be duplicated by you for your research use or educational purposes in electronic or print form. You must obtain permission for any other use. Electronic or print copies may not be offered, whether for sale or otherwise to anyone who is not an authorised user. 


\section{The significance of student voice: Female students' interpretations of failure in Tanzanian secondary education}

Hanna Posti-Ahokas and Elina Lehtomäki

Department of Teacher Education, University of Helsinki, Finland

Faculty of Education, University of Jyväskylä, Finland

In Tanzania, the national examinations are used as the primary tools for selection and transition from lower to upper secondary education. Female students are more likely to fail in the national exams and to drop out from education. This article examines the perspectives of female students concerning their advancement in secondary education. Two sets of qualitative data, responses to a research questionnaire from 100 female lower secondary school students and follow-up interviews with seven mature students enrolled in a non-formal school who had failed in the national examinations, were analysed to identify critical issues influencing the educational advancement of female students in an urban context of Dar es Salaam. Finally, the connections between students’ perspectives and the national secondary education development plan (SEDP) are examined. The aim is to highlight how student voice can contribute to transform secondary education and achieve the equality and equity targets.

Keywords: gender equality, secondary education, student voice, dialogic educational development, Tanzania, Sub-Saharan Africa 


\section{Introduction}

When you have 177,021 out of 354,042 failing, as it was the case in 2010 national Form 4 exams, then you know the nation is in trouble, more so when you consider that the pass mark is 21 per cent! (The Citizen 26 November 2012, Tanzania)

The recent poor results in the national lower secondary education examinations have generated heated debates in Tanzania. During the last years, there has been a dramatic decline in the results of final examinations in lower secondary education (Form 4) and the performance of girls has decreased proportionally more than that of boys. The pass rate in Form 4 examinations has steadily decreased from $86.15 \%$ in 2007 to $53.37 \%$ in 2011. In 2011, the pass rate for female students was 48.25\% compared with 57.5\%1 of male students (URT 2012). The national examinations are used as the primary tools for selection and transition. For students who aim to proceed to upper secondary education (Form 5 and 6) the Form 4 examinations form a bottleneck ${ }^{i}$. Transitions from primary to secondary and from lower to upper secondary education are critical stages for girls, in particular, and the dropout rates of girls in secondary education are higher than those of boys (Okkolin, Lehtomäki and Bhalalusesa 2010; Posti- Ahokas and Palojoki 2013). A significant proportion of students in secondary schools are over-aged due to repetition and drop-out caused by financial constraints within families and the school system and the low quality of education provision $^{\text {ii }}$ (e.g. Carr-Hill and Ndalichako 2005; URT 2011). In Tanzanian cities, the rapidly increasing private schools offer second chances for those who have dropped out of the formal system. This new phenomenon in Tanzania has stimulated public discussion on the role of national examinations and concerns over the quality of secondary education (e.g. Hartwig 2013). In the broader context of Sub-Saharan Africa, the situation in Tanzania looks serious, because the overall secondary education provision and enrolment rates are the lowest in the region (see e.g., AlSamarrai and Reilly, 2008).

In Tanzania, the Ministry of Education and non-governmental organisations (NGOs) have analysed reasons for the dramatically deteriorating results with the focus on administration and management, school environment and the examination procedures, teacher-related factors and curriculum implementation (HakiElimu, 2011a; URT and UNESCO, 2012). What seems missing from these analyses are the perspectives of students, female students in particular, who are most affected by the situation. Recent research in two neighbouring countries, Malawi (Kamwendo 2010) and Uganda (Jones 2011) shows that insights gained from ethnographic studies on female students can unfold the construction of gender and gendered experiences in education and thereby contribute to achievement of equity targets. Previous research further suggests that student voice is essential for the assessment of educational opportunities and critical aspects when aiming for meaningful educational change (Yonezawa, Jones and Joselowsky, 2009; Mitra and Gross, 2009; Warrington and Kiragu, 2012). Inspired by the evident potential of student voice work (McLeod, 2011), and student engagement for prevention of dropout (Yonezawa, 2009), this paper focuses on the female students' views on secondary education.

The high failure rate in lower secondary school national examinations triggered heated public debate in Tanzania on how the 'nation is in trouble'. Less attention was given to the fact that most of those failed in exams were female students who, therefore, are at a greater risk of dropping 
out of secondary education. The specific adversities, including discrimination in and out of school, early marriage and pregnancy, that female students face at the critical transitions between levels of education need to be better understood to move towards gender-responsive strategies and practices (Chabaan and Cunningham 2010; Okkolin, Lehtomäki and Bhalalusesa, 2010). This study investigates the examination failure and needs for change in secondary education from the perspective of female students. Special attention is given to views of over-aged students who are persistently working towards their personal goals in the margins of the education system (e.g. Warrington \& Kiragu 2012). The connections between students' perspectives and the national secondary education development plan (SEDP) are examined to highlight how student voice can contribute to transform secondary education and achieve the equality and equity targets.

\section{Gender equality in Tanzanian secondary education}

For the past decade, the development of secondary education in Tanzania has been guided by the national Secondary Education Development Plans 2004-2010 (SEDP I), and 2011-2015 (SEDP II) aiming at building a high quality, productive and adaptive labour force for the economy to contribute to realisation of the national development vision. The five key areas of the SEDP II include 1) improvement of quality and relevance, 2) enhancement of access and equity, 3) improvement of the teaching force and teaching process, 4) improving management efficiency and good governance and 5) institutionalization of cross-cutting issues, such as gender and HIV/AIDS awareness. SEDP defines strategic measures with the focus on the development of the education system and processes. The current SEDP recognises the lowered performance levels in examinations as an indicator of poor quality and, consequently, as a major issue to be addressed. One of the objectives of the SEDP is to improve the national examination assessment framework by reviewing the current status and impact of examination practices on results, and by establishing an appropriate assessment and examination system, possibly with reference to changes in other countries in the region. Recently Tanzanian media has paid attention to the further decline in the examination results since the beginning of the SEDP II period that has resulted in revision of examination grading system and nullification of the examination results of 2012 (The Citizen, Tanzania, 30 and 31 May 2013).

The current SEDP emphasises improving girls' participation and performance in the enhancement of access and equity in secondary education. While the gender parity has been reached in Tanzanian primary education, boys outnumber girls in secondary education and in upper secondary level the number of girls significantly declines (Al-Samarrai and Reilly, 2008; Okkolin, Lehtomäki and Bhalalusesa 2010; United Republic of Tanzania [URT] 2011). In 2011, the gross enrolment rate in lower secondary education was $45.9 \%$ for girls and $54.5 \%$ for boys, decreasing to $3.5 \%$ and $6.5 \%$ in upper secondary education. In terms of retention, the gross completion rate in 2011 for lower secondary education (Form 4) was 30.9\% for females and $40.7 \%$ for males and respectively 3.0\% and 5.4\% for upper secondary education (Form 6). Furthermore, as girls' performance in Form 4 examinations is significantly lower than that of boys throughout subjects (10 to 20 percentage points in subject pass rates), with the exception of Kiswahili language, where girls outperform boys. Consequently, the statistics suggest that girls remain remarkably disadvantaged with regards to access, advancement and educational outcomes (URT 2011). 
The poor quality is associated with the rapid expansion of access to secondary education, which in turn has had a negative impact on educational equality (Wedgwood, 2007). The SEDP recognises the widening gender gap in participation and the decline in examination results, and explicitly targets retention and examination performance of girls. Promoting retention, improving performance in science subjects and enhancing transition of female students to upper secondary education are defined as critical issues. Retention target of $90 \%$ is to be reached through providing girl friendly facilities (latrines and hostels), empowering girls' club activities, revising school rules and regulations and stakeholder sensitization through media. Girls' examination performance is to be enhanced by providing remedial tuition, user friendly learning materials and science camps (URT, 2010). The experiences and views of girls and young women are not, however, suggested as a measure for improving educational advancement and learning outcomes.

In Tanzania, as in other low-income countries in Sub-Saharan Africa, girls' educational attainment is tied to a complex set of issues ranging from policy to socio-economic and sociocultural factors (e.g. Okkolin 2013). In Tanzanian families and communities, poverty and cultural constructions of gender have been identified as major causes of gender based discrimination in access to education. (Vavrus 2002; 2005). Furthermore, early pregnancy is a major risk for educational advancement of secondary school age girls (Stambach 2000, Helgesson 2006, URT 2011, Posti-Ahokas 2012). Within secondary education, analysis of the constructions of gender in the teaching and learning process (Thomas and Rugambwa 2011) and the gendered school environment (Sommer 2010) have shown how efforts to remove discrimination against females are challenged by the complex discriminative discourses and practices operating within school contexts.

Egbo (2005) has argued that African girls are socialized to discriminatory gender role norms that are further reinforced when women themselves adopt and maintain a 'culture of silence' that excludes them from active participation in society. In this study, we privilege the voices of female students to better understand how they see the complex processes influencing their advancement in education. This study explores the potential contribution of female students, and identifies the critical issues from their perspective, concerning advancement in secondary education.

\section{Potential of student voice for educational change}

Grounded in critical research tradition and radical pedagogy (see Taylor and Robinson, 2009), student voice is defined as processes that enable students to be consulted on their education (Czerniawski, 2012) with the aim of increasing students' representation and participation in processes from which they have historically been excluded (Taylor and Robinson, 2009). McLeod (2011, p. 181) identifies four common overlapping uses of voice in educational discourse: 1) voiceas-strategy (to achieve empowerment, transformation, equality); 2) voice-as-participation (in learning, in democratic processes); 3) voice-as-right (to be heard, to have a say); and 4) voice-asdifference (to promote inclusion, respect diversity, indicate equity). In this study the female students' voice is understood as a significant contribution to the debate on secondary education, in McLeod's terms voice-as-right, in particular, to be heard and have a say concerning advancement and learning outcomes in secondary education in Tanzania.

As a political concept connected to justice and equality, voice is concerned with questions of power and knowledge, inclusion and exclusion and of being advantaged and disadvantaged (Thomson 2011). The popularity of student voice work within different educational systems has 
attracted significant academic interest and debate on its applicability in different contexts (for discussion, see Czerniawski, 2012). Along with the idealised, emancipatory purposes of student voice work, practices to involve students are often reduced to solely serve the aims of organisational efficiency while losing the potential for democratic development and transformation (Fielding, 2004; Gunter and Thomson, 2007). Critchley (2003) argues that in student voice work for policy development, students are commonly used as a source of data rather than as policy-makers.

Unterhalter (2012) has reminded of the importance of adequate contextual understanding for transformative use of girls' voice in African contexts, where young people's voices are easily silenced, respecting, as Kiragu et al. (2011) explain, the longstanding traditions of who talks, who listens and which topics are considered taboo. In Kenya, Jwan and Ong’ondo (2009) explored perceptions of students concerning participation in secondary schools, and found that the students felt their participation was peripheral and their contributions were not well-articulated in school decisions. Practices that the teachers and principals considered to be in the interests of students were viewed differently by the students, even in direct contrast to the expectations of the teachers and principals (Jwan, 2011). The involvement of students in decision-making was considered uncomfortable for teachers (Jwan, 2011). Juffermans and Van Camp (2013) showed how their analysis using student voice on language policy in Gambian education has contributed to critical evaluation of policy by unfolding the reasons for students' enthusiasm for learning in English despite the minimal learning outcomes. In her ethnography on girls' secondary education in Uganda, Jones (2011) concluded that the girls' views offered insights into their specific daily challenges and this knowledge is necessary for policy-making, if education planners are committed to achieving gender balance.

In the context of Tanzania, there is little documented evidence of student voice work within secondary schools. TUSEME ('Let Us Speak Out') clubs in secondary schools are the most wellknown and wide spread initiatives aimed at empowering girls and tackling gender-related problems. Initially an NGO initiative, Tuseme has now been scaled up by the Ministry of Education and Vocational Training and, where active, the clubs are forums for student participation in school improvement (FAWE, 2004; URT, 2010). Additionally, students have been involved as coresearchers to develop models for including students in curriculum development for HIV/AIDS prevention (Rutagumirwa and Kamuzora, 2006; McLaughlin and Swartz, 2011) and for science teaching and teacher training (Semali and Mehta, 2012). Methodological explorations with participatory group activities (Sommer, 2010), reflective writing and photography (Miles, 2011), empathy-based stories (Posti-Ahokas, 2012), and photo voice (Nguvu ya Sauti, 2012) have been conducted to study the sociocultural context beyond school from the students' perspectives.

Previous analyses of student voice work call attention to issues of trust, inclusion, dialogue, power and participation. Taylor and Robinson (2009) argue for the importance of recognising plural and context-specific relations of power and participation. Similarly, Czerniawski (2012) emphasises the existence of different forms of professional trust in different national locations. To include the other, silent and, perhaps, controversial voices is a requirement for achieving the potential of student voice work that can increase social justice (Robinson and Taylor, 2007). This is particularly relevant to the research involving student voice in African contexts where inequality and marginalization in education are critical issues.

Fielding (2009) sees the potential in research approaches involving student voice to encourage, enable and liberate - to remake the present and revision the future. Similarly, Cook- 
Sather (2006) argues for participatory research to counteract policy making and practices that systematically exclude students' perspectives. Fielding (2001) outlines a four-fold typology of practices involving student voice: a) students as data source, b) students as active respondents, c) students as co-researchers and d) students as researchers, indicating different levels of participation and authority of students where the last two are seen to have a stronger transformative potential. In this study, female students are seen as active respondents who reason and analyse their own educational advancement. Previous research from Tanzania shows that research can be designed to give voice to students who are often left out of discussions around education (Sommer, 2010; Billings, 2011; McLaughlin and Swartz, 2011; Posti-Ahokas, 2012; Lehtomäki et al., 2013). This study aims to analyse and document the voice of female students.

\section{Methods}

The research was conducted as part of a broader study in three public and in two private schools ${ }^{\mathrm{iii}}$ in Dar es Salaam, the largest city in Tanzania (reference removed for anonymity). Participants were selected from different types of schools to include the perspectives of girls representing a variety of socio-economic backgrounds. Data on female students' assessment of their own opportunities to proceed to upper secondary education were collected using a semi-structured research questionnaire on personal plans and future aspirations, distributed to and responded by 100 female students enrolled in Form 3, in December 2008. The students were asked about factors that they felt influenced their opportunities to realise their plans to advance in education. The focus of the analysis was to identify factors influencing advancement and retention in education, as seen by students. To engage the voices of female students who had dropped out and faced the risk of marginalisation, follow-up interviews were conducted a year later with seven young women aged between 23 and 28 years who were enrolled in a non-formal school ${ }^{\text {iv }}$, which mainly served mature students who had failed in the national examinations and, consequently, dropped out of the formal system. This groups represents, as Warrington and Kiragu (2012) define, those who against odds continue their education and, therefore, provide essential information about the education system's functionings. The students interviewed talked about their extended transition experience, the reasons for the generally low examination results, and their perspectives on how the performance of students and the educational system in general could be improved. In the results section, participants of the questionnaire study $(\mathrm{N}=100)$ are referred to as 'Form 3 students' and the seven interviewees of the follow-up study as 'mature students'.

The data collection was conducted in Kiswahili, the official language in Tanzania, the medium of instruction in primary education and the lingua franca in Dar es Salaam. In secondary education, the official medium of instruction is English, although, in practice, Swahili is often used in teaching (see Billings, 2011, for a discussion on language use and acquisition in Tanzanian secondary schools). The qualitative content analysis of SEDP II (URT 2010) focused on the critical issues identified during preparation of SEDP II, and the plan's objectives and strategies regarding the enhancement of access and equity. Finally, connections between the female students' perspectives and the policy articulations were examined. 


\section{Female students on advancement and failure in secondary education}

\section{Advancement in education}

In the responses to the questionnaire $(\mathrm{N}=100), 131$ mentions of the factors influencing advancement were coded and categorised as positive (contributing) or negative (constraining). The mentions were further grouped into self-related, school-related and socio-cultural factors. The distribution between the factors and categories are presented in Table 1.

\begin{tabular}{|c|c|c|c|c|c|}
\hline \multirow[b]{3}{*}{$\begin{array}{l}\text { Table } 1 . \\
\text { influencing } \\
\text { in education }\end{array}$} & \multirow[b]{3}{*}{$\begin{array}{l}\text { Factors } \\
\text { influencing } \\
\text { advancement } \\
\text { in education }\end{array}$} & \multirow{2}{*}{\multicolumn{3}{|c|}{ Assessment of own opportunities }} & \multirow[b]{3}{*}{$\begin{array}{l}\text { Factors } \\
\text { advancement }\end{array}$} \\
\hline & & & & & \\
\hline & & Examples & $\begin{array}{c}\% \text { of all } \\
\text { mentions }(n)\end{array}$ & $\begin{array}{l}\% \text { of positive/ } \\
\text { negative } \\
\text { mentions within } \\
\text { the category }\end{array}$ & \\
\hline & $\begin{array}{l}\text { Self-related } \\
\text { factors }\end{array}$ & $\begin{array}{l}\text { attitude, effort, } \\
\text { responsibility }\end{array}$ & $39(51)$ & $96 / 4$ & \\
\hline & $\begin{array}{l}\text { School-related } \\
\text { factors }\end{array}$ & $\begin{array}{l}\text { help from teachers, } \\
\text { peer support }\end{array}$ & $6(8)$ & $63 / 37$ & \\
\hline & $\begin{array}{l}\text { Socio-cultural } \\
\text { factors }\end{array}$ & $\begin{array}{l}\text { support from } \\
\text { parents and } \\
\text { extended family, } \\
\text { religion, negative } \\
\text { influence from } \\
\text { other people, } \\
\text { poverty of family }\end{array}$ & 55 (72) & $42 / 58$ & \\
\hline & Total & & $100(131)$ & & \\
\hline
\end{tabular}

Considering their situation prior to the final examinations in Form 4, the students emphasised the role of socio-cultural factors, particularly family, in determining their transition to Form 5 (55\% of all mentions). The role of economical and psychological support provided by the (extended) family was crucial: "Because my parents very much like to see me acquire adequate education and they do provide me with every service that I need, even though they themselves attained a simple formal education". In contrast, almost half of the respondents doubted if they could continue at all, mainly due to financial constraints in their families: "These expectations will never materialise because the guardians I am living with are not (financially) capable... Until right now, I am studying under problems - school contributions are a bother. I therefore think that I may completely not be able even to continue due to the condition of my guardians - they are elderly and unable". However, where support from the family is available, students took the responsibility for succeeding themselves (39\%): "I will study with the utmost diligence, and since my whole heart is in it, I will simply succeed".

Our analysis of the students' perspectives to advancement in education suggests that schoolrelated factors play only a marginal role in students' considerations. Only 6\% of the reasons mentioned for attainment were directly associated with school or government support. Eight school-related issues, three of which were negative effects of the schooling system, were mentioned in the responses. Students relied on support by the Government in providing opportunities for quality education "I know the Government of Tanzania will assist me". Peer support and being close 
to teachers were considered important for personal success. When considering their own opportunities to proceed to upper secondary education, three respondents saw high enrolment and competition as threats to their own advancement: "there are many of us studying in Form Four" and "there is very stiff competition in education nowadays, so, in fact I am not certain whether I will attain my dream".

These findings are in accordance with our previous findings (Posti-Ahokas, 2012) on the importance of socio-cultural factors (support from parents and extended family, peer support, religion), and the very limited role of school-related factors in students' considerations regarding advancement in education. While in school, persistence, effort and effective learning strategies are seen to greatly determine success. Similarly, previous studies in Kenya (Kakenya, 2011) and Tanzania (Okkolin, 2013) have shown that educated women consider their success as a combination of personal qualities, familial support and school-related factors. In the present study, the limited role of school-related considerations in the thinking of the Form 3 students places pressure on the female students themselves as the major cause for success or the lack of it. Internalising and personalising the lack of success caused by structural constraints can result in creation of a false sense of failure (Ansell 2004; Crivello 2011). Therefore, participation in evaluation and improvement of the learning environment at school (e.g. Sommer 2010) could both increase female students' awareness on the structural constraints to advancement in education and also contribute to dialogue required for improvement of equality in education.

\section{Voices of the 'failures' in Form 4 examinations}

At the time of the individual follow-up interviews, the students, families and schools throughout Tanzania were digesting the shockingly low examination results that also received significant media attention. We asked students who had dropped out of the formal educational system what, according to them, had caused the low examination results, and what, from their perspective, could be done to improve the performance of students and the educational system in general. In addition to the individual interviews with seven young women, we conducted complementary interviews with members of the school's student parliament ${ }^{\mathrm{v}}$, the school principal and the teachers to contextualise the individual experiences of the interviewed students.

The interviewees were aged between 23 and 28, which indicate irregularities in their educational paths. On their first attempt in taking the examinations in different schools, all seven women had failed to secure the credits required to enroll in upper secondary education. Three of the women had already taken the Form 4 examination twice (in 2008 and 2009). In the academic year of 2008-2009, all seven had attended a one year programme of the non-formal school comprising essential contents of the Form 3 and 4 syllabuses, preparing them to sit the national Form 4 examinations as private candidates in special examination centres. They had all taken the Form 4 examinations in November 2009 and had recently received the results when we conducted the interviews in March 2010. Two of them had passed the second time and proceeded to Form 5, three had re-registered for the preparatory programme, and two were considering whether and how to proceed. 
Shock and disappointment regarding the examination results were shared by the five students who had not passed the examinations with adequate marks to proceed to Form 5 . All of them thought they had been well-prepared and were expecting good results. Nuria (age 28) describes the shared disappointment:

Therefore, most of us think that results have not been good this year, and most of us did not so expect. We studied diligently, but now we do not know what the problem is. We do not understand, even though in our hearts and our understandings we deemed that we had performed well.

Two of the interviewees had immediately re-enrolled in the same preparatory class and were planning to re-take the examinations later the same year. Two were trying to find the financial resources to enroll in the preparatory class as soon as possible. Angelina (age 24) was now working and found her situation fairly hopeless:

Actually, for now it pains me, that is, I having not ... I have done nothing. I still see that I have done nothing because my goals were attached to reaching Form Four, and then find a course to pursue. Therefore, for now I see that it is difficult, that is, I have not yet got any light.

The disappointment was also shared by the school principal, the teachers and the members of the student parliament that we interviewed. Obtaining a full record of the results was difficult because students were taking the examinations as private candidates in different examination centres. After the results came out, the student parliament analysed the situation together with the school administration. This resulted in the initiation of an additional, teacher-led revision session each morning.

Analysing the reasons for one's own low examination results was difficult for the students. However, they articulated some possible reasons that had led to the overall poor performance:

Researcher: What do you think has caused the results to be so poor?

Kemi (age 23, passed the exam on second attempt): As for me, what has made the results to be undesirable is probably on our side as students. This is because we fail to read topics in the books written by the Ministry (of Education) or the Institute (of Education) for us to read. As a result we go and take books that people have already written, like those of Nyambari Nyagwini. Even last year, I did likewise. So you take and study the points; consequently, you find the points shallow, then you do not understand everything. When you go to write, you do not elaborate things adequately. It is just like those are the things misleading us students, reading things . . you do not get into class for meaningful reading, you begin struggling for other things.

As described by Kemi above, high failure rates have increased the demand for concise 'question and answer' materials that are marketed as a quick fix solution to students' learning needs. Both the students and the teachers recognised the risks related to the popularity of such materials. However, it was also recognised that the school was not able to provide adequate reading materials to all 
students. Decisions are made in favour of the commercially produced materials that are often cheaper than the government approved materials. The school principal confirmed the increase in using alternative, exam-oriented books and expressed his concern over access to proper learning materials. Also student parliament members saw the availability of materials as a key issue in improving students’ performance.

The students expressed their concerns about the unequal position of students in government schools compared to those enrolled in private, non-formal schools. Abolition of examination fees from students in government schools was seen to increase inequalities between students enrolled in different types of schools. Although some of the private schools provide for the more privileged, many schools, including the one where we conducted our research, are enrolling students from the poorest segments of the society. Therefore, it was suggested by the student parliament that the government would exempt the poorest students from the examination fees. Furthermore, the status of private candidates in the National Examinations seems generally vulnerable.

Like the way we did our examinations, our centre had so much disorder. And that is what made them decide to nullify it this year; it is no longer there, that is, examinations will no longer be conducted there, because they breached the procedures of the (National) Examination Council. Many students were taken away and some transferred to churches and whatever, intensifying the disorder. So I would like the government to take heed on such issues.(Suzy, 28)

When I see bad results, it is a big issue. Because we can blame Ministry of Education, in other side you can blame students. Because some students, for example I, I struggle with myself, I need to succeed but sometimes results can come negative . . . I think there are mistakes but because I'm not familiar with government issues that's why I can't give you full information. But I need to advice my fellow students - I used to struggle hard in order to escape these obstacles from the Education Ministry. (Eve, 25)

Similarly, the school principal considered the private candidates as victims of the system and said that the students' rights only seem to apply to students within the formal system. As a solution, the student parliament members called for more dialogue between the public and private education providers and the government to increase coherence in practices. As an example, more common tests for both school types were suggested to increase equal opportunities. Students were worried that they would be seen as second class workers by the employers. Despite all problems, students saw the non-formal, fast-track provision as a necessity:

There are so many Tanzanians who are poor... that's why all of us are not able to take all the years; Form, 1, 2, 3, and 4 - that's why we take a short cut. So I would like to say that the government should not stop this [programme]. (Interview with student parliament member) 


\section{Connections between the students' views and the Secondary Education Development Plan}

When assessing their own opportunities to proceed further in education, students emphasised the role of economical and psychological support provided by the (extended) family to greatly determine their transition. The students' perspectives of factors influencing advancement in education contrast with the objectives of the SEDP regarding access. The plan seems to place insufficient value on the role of families in supporting the secondary education of girls. The SEDP suggests using media, particularly newspaper articles, to sensitise stakeholders to strategies to promote the retention of girls. Our data from urban areas do not point to major problems in familial attitudes towards girls attaining higher levels of education, but rather reflect great commitment of families to support their daughters. However, previous research findings from Tanzania suggest that advocacy work is still needed to promote education of girls and women, particularly in rural communities (Stambach 2000; Vavrus 2005).

Due to the emphasis given by the students on the critical and controversial, both enabling and constraining, role of their families and community in their advancement in education, a further analysis of the SEDP documentation was done to identify policy articulations regarding schoolcommunity connections. Based on the analysis, the schools are seen to operate in isolation to a great extent. The community is mainly seen as a provider of income for the schools via various types of students' fees in both public and private schools. According to the latest Education Sector Analysis (URT and UNESCO, 2012), household direct and indirect investments are equivalent to 21\% of public recurrent education expenditure. This estimation does not include the significant contributions from the community to the construction of schools in terms of cash and labour. Furthermore, the SEDP designates new, significant responsibilities to communities for the construction of houses for teachers and hostels for students and for the provision of meals for students. Other than their contribution to fees and construction, the families and communities are not given any role in implementing the strategies of the SEDP. The only reference to networking with other governmental agencies and NGOs is found in strategies to establish care and support programmes for students and personnel affected by HIV/AIDS.

Form 3 students and mature students viewed economic problems in their families, high enrolment numbers and competition as threats to their own advancement in education. The unproportional expansion of lower secondary education has resulted in problems to accommodate the Form 4 leavers in further education. In 2010, the pass rate for Form 4 examinations was only $50.4 \%$ and only $4.3 \%$ gained the scores required for transition to Form 5 (URT 2011). The SEDP recognises the challenges resulting from the expansion and the increasing number of students from poor households. It includes a plan to expand provision of upper secondary education and a public scholarship scheme to assists youths from poor families. The qualitative evidence presented here regarding the scale of economic problems, even among students residing in the largest city of Tanzania, raises doubts about the ability of a small-scale scholarship scheme to make a difference. Even if all 80,000 eligible students availed of the scheme, scholarships would be available only to $5 \%$ of students enrolled in public secondary schools (calculated from enrolment figures for 2011 [URT, 2011] and SEDP projections). The SEDP acknowledges the roles of private and non-formal schools in expanding access and the non-government schools are included in national enrolment and performance statistics. The non-profit making nongovernment schools are also eligible for the capitation grants at the rate of $50 \%$ of what is paid to government schools. 
The Form 3 students emphasised the role of personal effort and learning strategies in advancement. The SEDP outlines the promotion of independent learning, as well as analytical and critical thinking skills of students, as objectives leading to improved performance in examinations. Evidence from studies conducted in government schools (Makombe et al., 2010; HakiElimu, 2011a) suggests that active learning is an objective yet to be reached in practice. Both the mature students and the headmaster of the non-formal school criticised the increased use of alternative materials containing old exam questions and model answers. The limited access to textbooks and to other quality learning materials is also recognised in the SEDP. Resources for the provision of materials are drawn from school fees paid by the students and their families, in addition to capitation grants paid by the government. However, a monitoring report by a Tanzanian NGO (HakiElimu, 2011b) suggested that capitation grants do not reach the schools on time and that the central government has not been able to budget for the capitation grants throughout the SEDP period.

The increasing failure rates have had severe impacts on the transitions of large number of students. The reliance on national examination results as the sole indicators of achievement result in prolonged transitions and generate an externally imposed sense of failure (Ansell 2004; Abdi and Cleghor 2005). The SEDP includes a plan to improve the national examination assessment framework. The further declining examination results and the heated public debates call for urgent action. The interviewed mature students had experienced disruption in the examinations and had suffered from nullification of their results. Taking examinations as a private candidate places students from non-formal schools in a more vulnerable position and leaves their schools with neither responsibility nor possibilities for a proper follow-up. The students enrolled in the private, non-formal institution regarded their status to be lower than that of the students in the public schools. These mature students called for more dialogue between public and private institutions and the government to increase the coherence and equality in secondary education. They valued the student parliament as a dynamic body intermediating issues between students and school administration. The current SEDP does not acknowledge student councils as part of the institutional arrangement and no data is available on their prevalence.

To summarise, the key findings regarding advancement in education, the transitions through Form 4 examinations and female students' suggestions for system improvement are presented in Table 2.

Increasing enrollment and economic problems are a concern shared both by the female students and the SEDP. The deteriorating quality of secondary education is reflected in the decreasing examination results, public debates and the lives of female students. According to the students, their (extended) families usually do their best to educate their daughters. Our findings suggest that more could be done to further benefit from the strong societal demand for female secondary education (see Billings 2011 for discussion) and the valuable insights of female students who are the major targets of equity efforts of the SEDP. 
Table 2. Secondary Education Development Plan II (SEDP) strategies related to the critical issues raised by the secondary school students regarding advancement and transition to upper-secondary education.

\begin{tabular}{|c|c|c|}
\hline Critical themes & Critical issues defined by students & $\begin{array}{l}\text { SEDP strategies related to the } \\
\text { issues raised by the students }\end{array}$ \\
\hline Role of family & $\begin{array}{l}\text {-Significant psychological and } \\
\text { financial support from (extended) } \\
\text { families } \\
\text {-Poverty and financial constraints in } \\
\text { families threaten participation and } \\
\text { advancement }\end{array}$ & $\begin{array}{l}\text {-Strategies to sensitise families and } \\
\text { to promote education of girls } \\
\text {-School-community connections } \\
\text { defined as financial and labour } \\
\text { contributions for both government } \\
\text { and nongovernment schools } \\
\text {-A small-scale scholarship scheme } \\
\text { for students from poor families }\end{array}$ \\
\hline Personal effort & $\begin{array}{l}\text {-Own responsibility and learning } \\
\text { strategies important for success }\end{array}$ & $\begin{array}{l}\text {-Promotion of independent and } \\
\text { active learning }\end{array}$ \\
\hline $\begin{array}{l}\text { Access to } \\
\text { learning } \\
\text { materials }\end{array}$ & $\begin{array}{l}\text {-Failures in examinations explained } \\
\text { by lack of appropriate learning } \\
\text { materials }\end{array}$ & $\begin{array}{l}\text {-Provision of adequate and } \\
\text { appropriate materials }\end{array}$ \\
\hline $\begin{array}{l}\text { Increasing } \\
\text { enrolment }\end{array}$ & $\begin{array}{l}\text {-High enrolment rates and } \\
\text { competition threaten advancement }\end{array}$ & $\begin{array}{l}\text { - Increasing provision of both O- } \\
\text { level and A-level education. } \\
\text { Acknowledgement of the roles of } \\
\text { non-formal and private schools in } \\
\text { expanding access }\end{array}$ \\
\hline $\begin{array}{l}\text { Transition } \\
\text { through Form } 4 \\
\text { examinations }\end{array}$ & $\begin{array}{l}\text {-Re-sitting examinations added costs } \\
\text { for the students and their families } \\
\text {-Violations and nullification of } \\
\text { results due to poor organisation of } \\
\text { examinations } \\
\text {-Vulnerable position of students } \\
\text { from non-formal schools as private } \\
\text { candidates }\end{array}$ & $\begin{array}{l}\text {-Improvement of the national } \\
\text { examination assessment by } \\
\text { reviewing the current status and } \\
\text { impact of examination practises } \\
\text {-Establishment of an appropriate } \\
\text { assessment and examination system }\end{array}$ \\
\hline $\begin{array}{l}\text { Mechanisms for } \\
\text { system } \\
\text { improvement }\end{array}$ & $\begin{array}{l}\text {-Student council as an important } \\
\text { body to increase student participation } \\
\text { in school improvement } \\
\text {-Dialogue between public and private } \\
\text { schools and the government }\end{array}$ & $\begin{array}{l}\text { - Student councils not recognised in } \\
\text { the institutional structure of SEDP } \\
\text { implementation. }\end{array}$ \\
\hline
\end{tabular}




\section{Towards transformative student voice work in secondary education development}

From the perspective of these findings, critical issues are what is the potential of student voice work in opening up new opportunities for female students' engagement in education and improving their educational transitions in Tanzania, and how can this research contribute to educational planning and policy implementation. In this study, education policy is seen as a multi-level process of negotiation, contestation and a struggle between competing groups (Ozga 2000). In common with previous studies on girls' voice in Tanzania (Billings, 2011; Sommer, 2010), the girls and young women in the present study had several relevant recommendations on how to improve schools and the education system. Their perspectives highlight the importance of understanding advancement and transitions in secondary education as a combination of personal effort, family support and the enabling structures of the education system and thereby complement the structural analysis on the construction of gender inequalities in education in Tanzania (e.g. Vavrus 2005; Chaaban and Cunningam 2010).

The experiences of the mature students in non-formal school illustrate the impacts of deteriorating quality and poor performance on individuals and families. Examining the connections between the female students' perspectives and the current SEDP measures shows that though the development plan does to some extent recognise the critical issues raised by students regarding advancement and transitions, it ignores the issues beyond the immediate school structures. Vavrus (2002) has argued that rather than traditional attitudes, economic policies undermine opportunities of Tanzanian children to stay in school. Our study supports Vavrus's statement by suggesting that the most important issue for both the female students and the realization of gender equality in secondary education is finances, significantly influencing quality and participation in secondary education. Therefore, further understanding of the complex connections between female students, their families and communities and the school system is needed to effectively work towards equity and equality targets (see also Okkolin, Lehtomäki and Bhalalusesa 2010; Jones 2011; Okkolin 2013).

The perspectives of mature students who are struggling to make the transition to upper secondary education provide valuable insights to the realities of female students within the examination oriented system. The female students in the non-formal school who had previously failed in national exams had actively sought to re-enter school. However, they reported that as private candidates they did not receive equal treatment in the national exams. To include these silent and, perhaps, controversial voices is a requirement for achieving the potential of student voice work that can increase social justice (Robinson and Taylor 2007; Warrington and Kiragu 2012). This issue is particularly relevant to this research involving the voices of female students in Sub-Saharan African contexts where inequality and marginalisation in education are critical issues, particularly in post-primary education. Therefore, improving the examination system in a gender sensitive manner would greatly benefit from information gathered through qualitative analysis of the experiences of female students in different school contexts and, as Vavrus (2005) suggested, in local settings beyond education.

When making recommendations, the participants referred to 'the government' instead of any levels in between, such as secondary school teachers, school leadership and committees. This may mean that the students perceived the educational system as centrally controlled and viewed the teachers and leadership as powerless to change this system, e.g., how the examination process was 
designed and conducted. An alternative interpretation is that their teachers and school leadership pointed to 'the government' when trying to explain the evident failures of the secondary schooling due to the poor quality and massive expansion. This refers to what Taylor and Robinson (2009) highlighted as the importance of recognising plural and context-specific relations of power and participation. Similarly, Czerniawski (2012) emphasised the existence of different forms of professional trust in different national locations. From the perspective of those female students who participated in this study, 'the government' needs information, but the students do not have mechanisms to speak back to policy. The findings provide a clear call for educational leadership and research to search for ways to include students' voices in dialogue at different levels of the educational system. They also highlight the need to re-define responsibilities for schooling and schools and to enforce collaboration between the government, different types of schools, NGOs and community-level initiatives (see Phillips, 2011, for discussion on the tensions of democratizing policy making in Tanzania).

The mature female students and members of student parliament called for including the voices of students in dialogic improvement of schools and the education system as a whole. According to Critchley (2003), for students to actively take part in development and implementation of education policy, their participation has to be formalized at all levels. In contrast, Green (2010) argues that the heavily institutionalized participatory planning mechanisms used in Tanzanian development activities has made participation to work against its intended benefits. Furthermore, social structures and cultural norms may limit students to voice their concerns (Unterhalter 2012), whether formalized or not. Therefore, introducing participatory approaches within development of education should be done with caution to retain the transformative potential of student participation at all levels. We argue that qualitative research can greatly complement the formalized student voice by including the silent and marginalised voices, allowing for a rich contextual understanding.

Recognising the threats regarding misuse of student voice (Gunter and Thomson, 2007) and lessons learnt from previous work done in African countries (Jwan and Ong'ondo, 2010; McLaughlin and Swartz, 2011; Posti-Ahokas, 2012; Unterhalter 2012) we emphasise the importance of cultural and contextual understanding for successful implementation of student voice work. Involving students as co-researchers and creating opportunities for student-led research could enhance collaborative development in schools and contribute to the education of teachers. Previous experiences of involving Tanzanian students and teacher students in curriculum development (Rutagumirwa and Kamuzora, 2006; McLaughlin and Swartz, 2011; Semali and Mehta, 2012) provide with encouraging experiences of student participation beyond serving as a source of data. Examining the student voice and the connections between their voice and the secondary education development plan but failing to include the voice in the development dialogue with policy-makers is a limitation of this study. Inclusion in the dialogue is, however, the long-term plan of the broader research project that this study is a part of.

Based on her analysis of the potential of student voice in equity initiatives in higher education, McLeod (2011, p. 187) argues that rather than inciting students' voices, the challenge is to convert those voices into meaningful and practical recognition and actions through 'a politics of listening'. She further suggests that re-framing student voice in a politics of listening would result in recognition, engaged dialogue and relevant action, thereby reviving the voice as a strategy for equity and inclusion. By highlighting female students’ views on failure and advancement in secondary education this paper contributes to the research dialogue, though further efforts are 
necessary to include the student voice in educational development in Tanzania. The government is committed to the achieving the equity and inclusion targets in secondary education and here the politics of listening could provide a new strategy to enhance the desired transformation in education. The discriminative structures, policies and practices within education place females in and out of school at a higher risk of marginalisation (Chaaban and Cunningham 2010; Warrington and Kiragu 2012). This study accords with the view that the perspectives of students can provide valuable, complementary perspectives to the complex problems related to equity and equality of education (Okkolin, Lehtomäki and Bhalalusesa 2010; Jones 2011; Kiragu et al. 2011). Also the research community and NGOs can contribute with their findings and knowledge concerning student voice work. As recommended by the students, the "government should listen". Our argument is that listening to female students, both to those who succeed in national exams and those who fail and face the risk of dropping out from the formal educational system, opens a window to relevant recommendations from motivated young females, eager to learn and find ways towards meaningful learning.

\section{Notes}

\footnotetext{
${ }^{\mathrm{i}}$ The Tanzanian education system consists of seven years of primary education (Standards I-VII, age group 7-13), followed by four years of lower secondary education (O-level, Forms I-IV, age group 14-17) and two years of upper secondary education (A level, Forms V-VI, age group 18-19). Primary education is public and free. Secondary education in both public and private schools is fee based (URT and UNESCO 2012). Within the categories of public and private school, there is a variety in resources and performance (Hartwig 2013; Posti-Ahokas \& Palojoki 2013). Therefore, the division between public and private is not of relevance for this research.

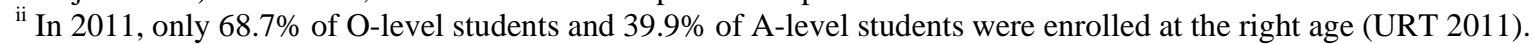

iii The schools were given the labels of 1) 'new community school', 2) 'established community school', 3) 'high performance government school' 4) 'established private school' and 5) 'NGO education centre'. Schools 1-3 are classified as public and schools 4-5 as private. All schools were following the same national curriculum.

iv School 5 'NGO education centre' is run by a non-governmental organisation and is classified as a private school. N.B. The status of private schools varies from high-performance and well-resourced ones to low-performance and poorly resourced institutions (see Hartwig 2013; Posti-Ahokas \& Palojoki 2013)

${ }^{\mathrm{v}}$ The student parliament consists of three members elected through a general vote. The purpose of the student parliament's work is to link students with school administration, to help administration to solve problems, to assist in achieving results and to organise extra- curricular activities, including academic clubs and study tours.
} 


\section{References}

Abdi, A. A., and A. Cleghorn. 2005. Sociology of Education: Theoretical and conceptual perspectives In Abdi, A. A. \& Cleghorn, A. (Eds.) In Issues of African Education. Sociological Perspectives, 3-24. New York: Palgrave McMillan.

Al-Samarrai, S., and B. Reilly. 2008. Education, employment and earnings of secondary school and university leavers in Tanzania: Evidence from a tracer study. The Journal of Development Studies, 44 (2), 258-288. doi: 10.1080/00220380701789950

Ansell, N., 2004. Secondary schooling and rural youth transitions in Lesotho and Zimbabwe. Youth \& Society, 36(2), 183-202.

Billings, S. 2011. Education is the key of life: Language, schooling, and gender in Tanzanian beauty pageants. Language \& Communication, 31, 295-309. doi: 10.1016/j.lang comm.2011.02.003

Chabaan, J. and Cunningham, W. 2010. Measuring the Economic Gain of Investing in Girls. The Girld Effect Dividend. The World Bank Policy Research Working Paper 5753. Retrieved from: http://wwwwds.worldbank.org/servlet/WDSContentServer/WDSP/IB/2011/08/08/000158349 20110808 092702/Rendered/PDF/WPS5753.pdf

Cook-Sather, A. (2006). Change based on what students say: Preparing teachers for a paradoxical model of leadership. International Journal of Leadership in Education, 9(4), 345-358. doi: $10.1080 / 13603120600895437$

Critchley, S. 2003. The nature and extent of student involvement in educational policy-making in Canadian school systems. Educational Management \& Administration, 31(1), 97-106. doi: 10.1177/0263211X030311007

Crivello, G., 2011. 'Becoming somebody': Youth transitions through education and migration in Peru. Journal of Youth Studies, 14(4), 395-411.

Czerniawski, G. 2012. Repositioning trust: A challenge to inauthentic neoliberal uses of pupil voice. Management in Education, 26(3), 130-139. doi: 10.1177/0892020612445685

Egbo, B. 2005. Women's Education and Social Development in Africa In Abdi, A. A. \& Cleghorn, A. (Eds.) In Issues of African Education. Sociological Perspectives. New York: Palgrave McMillan, pp. 141-158

FAWE 2004. Tuseme, “Speak Out”- Empowering girls, Tanzania. Retrieved from: http://www.fawe.org/Files/fawe_best_practices_-_tuseme_empowerment_tanzania.pdf

Fielding, M. 2001. Students as radical agents of change. Journal of Educational Change, 2(2), 123 141. doi: 10.1023/A:1017949213447

Fielding, M. 2004. Transformative approaches to student voice: Theoretical underpinnings, recalcitrant realities. British Educational Research Journal, 30(2), 295-311. doi: 10.1080/0141192042000195236

Fielding, M. 2009. Interrogating student voice. In Daniels et al. Educational theories, cultures and learning. A critical perspective. United Kingdom: Routledge.

Green, M. 2010. Making Development Agents: Participation as Boundary Object in International Development. The Journal of Develoment Studies 46(7), 1240-1263

DOI:10.1080/00220388.2010.487099 
Gunter, H., \& Thomson, P. (2007). Learning about student voice. Support for Learning, 22(4),181 188. doi: 10.1111/j.1467-9604.2007.00469.x

HakiElimu. 2011a. Are our teachers qualified and motivated to teach? A research report on teachers' qualifications, motivation and commitment to teach and their implications on quality education. Dar es Salaam: Hakielimu. Retrieved from: http://somatanzania.org/wpcontent/uploads/2012/08/Are-Our-Teacher-Motivated-and-Qualified-to-Teach.pdf

HakiElimu. 2011b. One year of implementing SEDP II. Are objectives and expectations met? (HakiElimu Brief 11:5E) Retrieved from:

http://hakielimu.org/files/publications/One\%20year\%20of\%20Implementation\%20SEDEP\%2 0II.pdf

Hartwig, K. A. 2013. Using a social justice framework to assess educational quality in Tanzanian schools. International Journal of Educational Development 33(5), 487-496.

Jones, S.K. 2011. Girls' secondary education in Uganda: assessing policy within the women's empowerment framework. Gender and Education, 23 (4), 385-413.

Juffermans, K., and K. Van Camp. 2013. Engaging with Voices: Ethnographic Encounters with the Gambian Language-in-Education Policy. Anthropology \& Education Quarterly, 44(2),142160. doi: 10.1111/aeq.12012

Jwan, J. O. 2011. In the "best interest" of the student: Perceptions and implications for leadership practices in secondary schools in Kenya. Management in Education, 25(3), 106-111. doi: $10.1177 / 0892020611398927$

Jwan, J. O., and C. Ong’ondo. 2009. Students' participation in the decision-making process in a secondary school in Kenya: Perceptions and implications in a changing school management context. Journal of Educational Leadership, Policy and Practice, 24(2), 41-51.

Kakenya, E. N. 2011. Warrior's spirit: The stories of four women from Kenya's enduring tribe. PhD Dissertation University of Pittsburgh. Retrieved from: http://dscholarship.pitt.edu/10481/1/Kakenya_ETD_2011.pdf

Kamwendo, M. 2010. Constructions of Malawian boys and girls on gender and achievement, Gender and Education, 22:4, 431-445 doi: 10.1080/09540250903341112

Kiragu, S., C. Swartz, J. Chikovore, F. Lukalo, and G.Y. Oduro. 2011. Agency, Access, Silence and Ethics: How Young People's Voices from Africa can Contribute to Social and Educational Change in Adult-Dominated Societies. In. Day, C. (ed.) International Handbook of Teacher and School Development, 254-263. London and New York: Routledge.

Lehtomäki, E., H. Janhonen-Abruquah, M. Okkolin, H. Posti-Ahokas, M. Tuomi and P. Palojoki. 2013. Research to engage voices on the ground in educational development. International Journal of Educational Development. http://dx.doi.org/10.1016/j.ijedudev.2013.01.003

Makombe, I., A. Kihombo, J. Sesabo, A. Hodgson and K. Spours. 2010. Building partnerships for poverty reduction in Tanzania. Improving Successful Completion and Progression from Secondary Education to further study and into working life. A collaborative research report, University of London \& Mzumbe University. Retrieved from: http://www.ioe.ac.uk/mzumbeioe_report_5-11-10_final.pdf

McLaughlin, C., and S. Swartz. 2011. Can we use young people's knowledge to develop teachers and HIV-related education? Prospects, 41(3): 429-444. doi: 10.1080/09540253.2012.721538 
McLeod, J. 2011. Student voice and the politics of listening in higher education. Critical Studies in Education, 52(2), 179-189. doi: 10.1080/17508487.2013.740678

Miles, S. 2011. Exploring understandings of inclusion in schools in Zambia and Tanzania using reflective writing and photography. International Journal of Inclusive Education, 15(10), 1087-1102. doi: 10.1080/13603116.2011.555072

Mitra, D., and S. Gross. 2009. Increasing student voice in high school reform. Building partnerships, improving outcomes. Educational Management Administration Leadership,37(4), 522—543. doi: 10.1177/1741143209334577

Nguvu ya Sauti. 2012. 'Photovoice' to empower Tanzanian youth. http://www.indiegogo.com/nguvu-ya-sauti?c=home

Okkolin, M-A. 2013. Highly Educated Women in Tanzania - Constructing Educational Well-being and Agency. Jyväskylä: Jyväskylä Studies in Education, Psychology and Social Research: 483.

Okkolin, M., E. Lehtomäki and E. Bhalalusesa. 2010. The successful education sector development in Tanzania - comment on gender balance and inclusive education. Gender \& Education, 22(1), 63-71. doi: 10.1080/09540250802555416

Ozga, J. 2000. Policy research in educational settings: contested terrain. Glasgow: OpenUniversity Press.

Phillips, K. 2011. Educational policymaking in the Tanzanian postcolony: Authenticity, accountability, and the politics of culture. Critical Studies in Education, 52(3), 235-250. doi: 10.1080/17508487.2011.604074

Posti-Ahokas, H. 2012. Empathy-based stories capturing the voice of female secondary school students in Tanzania. International Journal of Qualitative Studies in Education, doi: 10.1080/09518398.2012.731533

Posti-Ahokas, H. \& Palojoki, P. (2013). Navigating transitions to adulthood through secondary education: aspirations and value of education for Tanzanian girls. Journal of Youth Studies. doi: 10.1080/13676261.2013.853871

Robinson, C., and C. Taylor. 2007. Theorizing student voice: Values and perspectives. Improving Schools, 10(1), 5-17. doi: 10.1177/1365480207073702

Rutagumirwa, S.K., and P. Kamuzora. 2006. Secondary school students' voice in HIV/AIDS prevention interventions in Tanzania: A case study of Mbeya region. Retrieved from http://www.equinetafrica.org/bibl/docs/CBP1AIDSKamuzora.pdf

Semali, L. M., and K. Mehta. 2012. Science education in Tanzania: Challenges and policy responses. International Journal of Educational Research, 53, 225-239. doi: 10.1016/j.ijer.2012.03.012

Sommer, M. 2010. Where the education system and women's bodies collide: The social and health impact of girls' experiences of menstruation and schooling in Tanzania. Journal of Adolescence, 33, 521-529. doi: 10.1016/j.adolescence.2009.03.008

Stambach, A. 2000. Lessons from mount Kilimanjaro: Schooling, community, and gender in East Africa. New York, NY: Routledge.

Taylor, C., and C. Robinson. 2009. Student voice: Theorising power and participation. Pedagogy, Culture \& Society, 17(2), 161-175. doi: 10.1080/14681360902934392 
The Citizen, Tanzania. 2012. Blame exam failures to our bad attitudes. November 26. Retrieved from: http://www.thecitizen.co.tz/editorial-analysis/19-editorial-comments/27441-blameexam-failures-to-our-bad-attitudes.html

The Citizen, Tanzania. 2013. Failure rate down 10pc in new Form 4 results. May 30. Retrieved from: http:/www.thecitizen.co.tz/News/Failure-rate-down-10pc-in-new-Form-4-results//1840392/1867822/-/m9tc8wz/-/index.html

The Citizen, Tanzania. 2013. Educator quits Pinda's team in protest of 'new' F4 results. May 31. Retrieved from: http://www.thecitizen.co.tz/News/Educator-quits-Pinda-s-team-in-protest-of-new--F4-results/-/1840392/1868870/-/item/1/-/i9u0fxz/-/index.html

Thomas, M. A and Rugambwa, A. 2011. Equity, Power, and Capabilities: Constructions of Gender in a Tanzanian Secondary School. Feminist Formations, 23(3), 153-175

Thomson, P. 2011. Coming to terms with 'voice'. In Czerniawski, G. and W. Kidd. (Eds.) 2011. The student voice handbook: bridging the academic/practitioner divide, 19-30. Bingley: Emerald Group Publishing.

United Republic of Tanzania (URT). 2010. Secondary education development plan. Dar es Salaam: Ministry of Education and Vocational Training. Retrieved from: http://www.eddpg.or.tz/pdf/CCI/Secondary\%20Education\%20Development\%20Plan\%202010-2015.pdf

United Republic of Tanzania (URT). 2011. Basic education statistics in Tanzania 2007-2011. National data. Dar es Salaam, the Ministry of Education and Vocational Training.

United Republic of Tanzania (URT). 2012. Certificate of secondary education examination (CSEE) - 2011 report and analysis of the results. Dar es Salaam, the Ministry of Education and Vocational Training. Retrieved from: sescotz.com/sesco_files/Takwimu\%20CSEE\%202011.pdf

United Republic of Tanzania., and UNESCO. 2012. Tanzania education sector analysis. Retrieved from: http://www.ed-dpg.or.tz/pdf/ESPR\%20and\%20AM/Education\%20Sector\%20AnalysisExecutive\%20Summary.pdf

Unterhalter, E. 2012. Inequality, capabilities and poverty in four African countries: girls' voice, schooling, and strategies for institutional change. Cambridge Journal of Education 43(3), 307-325.

Vavrus, F. 2002. Uncoupling the Articulation Between Girls’ Education and Tradition in Tanzania. Gender and Education, 14(4), 367-389.

Vavrus, F. 2005. Adjusting Inequality: Education and Structural Adjustment Policies in Tanzania. Harvard Educational Review, 75(2), 174-201.

Warrington, M. \& S. Kiragu. 2012. “It makes more sense to educate a boy”: Girls 'against the odds' in Kajiado, Kenya. International Journal of Educational Development 32 (2012) 301309.

Wedgwood, R. 2007. Education and poverty reduction in Tanzania. International Journal of Educational Development, 27(4), 383-396. http://dx.doi.org/10.1016/j.ijedudev.2006.10.005

Yonezawa,S., Jones, M. \& Joselowsky, F. 2009. Youth engagement in high schools: Developing a multidimensional, critical approach to improving engagement for all students. Journal of Educational Change, 10(2-3), 191-209. doi: http://dx.doi.org/10.1007/s10833-009-9106-1. 